
ПОВЫШЕНИЯ КВАЛИФИКАЦИИ ПРЕПОДАВАТЕЛЕЙ СРЕДНЕГО ПРОФЕССИОНАЛЬНОГО ОБРАЗОВАНИЯ В ОБЛАСТИ ИНФОРМАТИЗАЦИОННОЙ БЕЗОПАСНОСТИ В УСЛОВИЯХ ЦИФРОВИЗАЦИИ

THEORETICAL FOUNDATIONS OF THE STUDY OF THE PROBLEM OF INCREASING QUALIFICATIONS OF TEACHERS OF SECONDARY VOCATIONAL EDUCATION IN THE FIELD OF INFORMATION SECURITY IN DIGITALIZATION

O. Kozlov S. Taraskina

Summary: The article is devoted to the urgent problem of personal information security today, which can be ensured by the formation of the information culture of the younger generation. Responsibility for this process lies with the pedagogue, the formation and development of information competence of which is one of the tasks of continuing professional and pedagogical education.

The subject of the study is the methodological support of the formation of competence in the field of information security among teachers of secondary vocational education in the continuing education system. The purpose of the study is to theoretically substantiate, develop and test methodological support for the formation of competence in the field of information security among teachers of secondary vocational education in the continuing education system. The methodological provisions of the study are: system analysis, ensuring the integrity of the consideration of the subject of research; competency-based approach to the continuing education process. The following methods were used in the study: theoretical; empirical; study of literary sources on the problem of research, observation, conversation, questionnaires, testing, pedagogical examination, monitoring and evaluation, statistical methods. The scientific novelty of the study is to identify the organizational and methodological conditions for the formation and development of information competence of teachers of secondary vocational education in the continuing education system.

The problem of information security of a person is solved, among other things, by the formation and development of information competence of teachers in the system of advanced training, which is one of the conditions for the organizational and methodological support of information security of a person.

Keywords: information security, information competence, information and communication technologies, information resources, ICT competencies, information culture, information and educational environment, unauthorized access, advanced training, security risk.
Козлов Олег Александрович,

Д.п.н., професссор, в.н.с., ФГБНУ «Институт стратегии развития образования Российской академии

образования»,

ole-kozlov@yandex.ru

тараскина Светлана Николаевна

аспирант, ФГБОУ ВО «Ивановский государственный университет

(Шуйский филиал)» zam-po-vr@mail.ru

Аннотация: (татья посвящена актуальной сегодня проблеме информационной безопасности личности, которая может быть обеспечена становлением информационной культуры подрастающего поколения. Ответственность за этот процесс возложена на педагога, формирование и развитие информационной компетентности которого составляет одну из задач непрерывного профессионально-педагогического образования.

Предметом исследования является методическое обеспечение формирования компетентности в области информационной безопасности у преподавателей среднего профессионального образования в системе повышения квалификации. Цель исследования - теоретически обосновать, разработать и апробировать методическое обеспечение формирования компетентности в области информационной безопасности у преподавателей среднего профессионального образования в системе повышения квалификации. Методологическими положениями исследования выступают: системный анализ, обеспечивающий целостность рассмотрения предмета исследования; компетентностный подход к процессу повышения квалификации. В исследовании использованы следующие методы: теоретические; эмпирические; изучение литературных источников по проблеме исследования, наблюдение, беседа, анкетирование, тестирование, педагогическая экспертиза, мониторинг и оценка, статистические методы. Научная новизна исследования состоит в выявлении организационно-методических условий формирования и развития информационной компетентности преподавателей среднего профессионального образования в системе повышения квалификации.

Проблема информационной безопасности личности решается, в том числе, формированием и развитием информационной компетенции преподавателей в системе повышения квалификации, которое является одним из условий организационно-методического обеспечения информационной безопасности личности.

Ключевые слова: информационная безопасность, информационная компетентность, информационно-коммуникационные технологии, информационные ресурсы, ИКТ-компетенции, информационная культура, информационно-образовательная среда, несанкционированный доступ, повышение квалификации, угроза безопасности. 
$\Pi$ едагогическая компетентность современного преподавателя среднего профессионального образования в числе предметно-методических и психолого-педагогических компетенций, включает так называемые ИКТ-компетенции.

Компетентность преподавателя среднего профессионального образования в области использования информационно-коммуникационных технологий может быть представлена одним из компонентов профессионально-педагогической компетентности, состоящего из знаний о современной компьютерной технике, информационных и коммуникационных технологиях (ИКТ), а также практических умений информационной деятельности, в том числе, с использованием сетевых сервисов в процессе своей профессионально-педагогической деятельности.

Анализ научно-педагогической литературы по проблеме компетентности преподавателя среднего профессионального образования в области использования средств ИКТ показывает, что понятие информационная компетентность, несмотря на его новизну, имеет достаточно много трактовок.

Здесь следует оговориться, что мы используем термины - «информационная компетентность», «компетентность в области использования информационнокоммуникационных технологий», «информационная компетентность», как синонимы, если не будет указания на иной смысл термина.

О.Н. Ионова определяет информационную компетентность как систему знаний и умений педагога в области информационных и коммуникационных технологий, а также практического опыта их применения в образовательном процессе [6].

П.В. Беспалов информационную компетентность педагога рассматривает как его обобщенную характеристику, проявляющуюся в активном усвоении знаний и способов деятельности с использованием компьютерной техники и информационно-коммуникационных технологий [2].

Обобщая приведенные определения информационной компетентности преподавателя среднего профессионального образования, можно утверждать, что сформированные знания и практические умения позволяют:

- реализовать дидактические возможности информационных и коммуникационных технологий в процессе обучения;

- осуществлять информационную деятельность и информационное взаимодействие между участниками образовательного процесса при использовании сетевых информационных ресурсов;
- оценивать психолого-педагогические и содержательно-методические качества электронных образовательных ресурсов в составе учебно-методических комплексов;

- обеспечивать информационную безопасность при использовании информационно-коммуникационных технологий и сетевых информационных ресурсов в образовательном процессе;

- автоматизировать информационно-методическое обеспечение и организационное управление образовательного процесса на базе информационно-коммуникационных технологий.

Таким образом, под информационной компетентностью преподавателя среднего профессионального образования понимается его готовность к организационно-методическому обеспечению учебной деятельности информационно-образовательной среды, целью которой является повышение уровня информированности, профессиональной и общекультурной компетенции участников образовательного процесса.

Информационно-образовательную среду следует рассматривать в качестве интеграции ИКТ организационно-методического обеспечения образовательного процесса с целью повышения его результативности за счет активизации учебной деятельности обучающихся.

Формирование и развитие информационной компетентности преподавателей среднего профессионального образования выступает одной из целей повышения квалификации.

Информационная компетентность преподавателя среднего профессионального образования предполагает развитие в процессе повышения квалификации следующих компетенций:

- владение понятиями, связанными с информацией;

- применение информационно-коммуникационных технологий при реализации профессионально-педагогической деятельности;

- владение методами и способами осуществления поиска, оценки, обработки, представления, хранения и распространения информации;

- оценка достоверности и полноты информации;

- способность осуществлять мониторинг и диагностику использования информационных продуктов [9].

Организационно-методические условия формирования информационной компетентности преподавателей среднего профессионального образования предполагают широкое использование информационно-коммуникационных технологий как предмета теоретического изучения, так и в режиме средства обучения в информа- 
ционно-образовательной среде повышения квалификации.

Модель изучения информационно-коммуникационных технологий как предмета в программе формирования информационной компетентности преподавателей среднего профессионального образования реализована в форме групповой работы с использованием метода проектов, нацеленного на решение некоторой проблемы [12].

Результативность активных методов формирования информационной компетентности обусловлена соблюдением ряда организационных принципов проведения практического обучения в процессе повышения квалификации, среди которых можно указать следующие принципы:

- максимального соответствия учебных ситуаций модели профессионально-педагогической деятельности слушателя;

- содержательной полноты учебных ситуаций, с привлечением опыта и примеров успешного профессионально-педагогического опыта слушателей;

- профессионально-личностного подобия восприятия учебных ситуаций, как реальной профессионально-педагогической деятельности;

- доступности значимой информации, а также простотой способов предоставления информации.

Результативность использования программного обеспечения информационно-образовательной среды образовательного учреждения среднего профессионального образования в качестве дидактического средства в программе формирования информационной компетентности зависит от того, насколько его использование педагогически целесообразно и соответствует решаемой с его помощью педагогической задачи [14].

Одним из основных требований к информационно-образовательной среде образовательного учреждения является наличие средств и методов фильтрации информации, обеспечивающих информационную безопасность пользователей информационных ресурсов.

Анализ научной литературы по проблеме информационной безопасности в образовании позволяет утверждать, что теоретические и практические вопросы обеспечения информационной безопасности всех пользователей информационно-образовательной среды образовательного учреждения является актуальной.

С общенаучных позиций «безопасность - отсутствие опасности для объекта (субъекта) или защищенность от нее. Понятие «угроза», как правило, применяется для характеристики возможного негативного воздействия природных или техногенных сил» [10].

С.В. Камашев расширяет понятие безопасности, утверждая, что безопасность характеризуется не только как отсутствие опасности, как свойство объекта или субъекта противостоять угрозам, но как особый вид деятельности по предотвращению угроз [7].

Предпринимаемые действия по обеспечению информационной безопасности направлены, в первую очередь, на определение уровня угрозы, ее устранения или поддержания в заданных пределах. При этом уровень угрозы негативного информационного воздействия (низкий, высокий, неопределенный), представляет собой основной показатель безопасного использования того или иного информационного продукта.

Все многообразие возможных информационных воздействий, несущих угрозы личности и обществу, условно можно подразделить на группы:

1. Угрозы нарушения прав личности.

2. Недобросовестное информационное воздействие.

3. Недостоверная, вредоносная информация.

Информационную безопасность в образовании рассматривают относительно безопасности информационно-образовательной системы образовательного учреждения или отдельной личности.

Так, М.В. Балашова определяет информационную безопасность информационно-образовательной системы как «такое ее состояние, при котором система подготовлена к противодействию, дестабилизирующему внешнему или внутреннему воздействию и функционирование которой не представляет информационной угрозы для внешней среды» [1].

Ю.И. Богатырева определяет информационную безопасность личности с точки зрения условий жизнедеятельности личности, включающих средства защиты от вредоносного или нежелательного информационного воздействия [4].

Г.В. Грачев рассматривает информационную безопасность личности как «состояние защищенности от действия таких информационных факторов, которые затрудняют или препятствуют осуществлению адекватной информационно-ориентировочной основы деятельности и социального поведения человека» [5].

Современные угрозы информационной безопасности, которые следует учитывать преподавателю среднего профессионального образования в профессиональной деятельности, представляют собой, в частности:

- несанкционированный доступ к персональным 
данным персонала и студентов образовательного учреждения;

- сбои в работе аппаратного или программного обеспечения информационно-образовательной системы, посредством намеренного вмешательства

- умышленная или случайная порча или физическое уничтожение аппаратных, программных средств и хранящейся информации;

- использование нелицензионного и вредоносного программного обеспечения в информационнообразовательной среде [4].

Задачами формирования компетенции в области информационной безопасности преподавателя среднего профессионального образования являются овладение:

- знаниями в области информационной безопасности;

- методами защиты персональных данных и учебной информации;

- практическими навыками обеспечения информационной безопасности в профессиональной деятельности.

Теоретическая подготовка преподавателя среднего профессионального образования в области информационной безопасности включает:

- понятие информационной безопасности;

- современные подходы к обеспечению информационной безопасности;

- правовые вопросы безопасного использования информации (защиты персональных данных, защиты авторских прав и др.);

- принципы безопасного использования информационно-образовательных систем.

Овладение преподавателем среднего профессионального образования методами защиты персональных данных и учебной информации направлено на распознавание вредоносной информации, фильтрации информационного потока, установление действенного контроля за сетевым контентом, противодействие вредному информационному воздействию [13].

Практические навыки преподавателя среднего профессионального образования в обеспечении информационной безопасности в профессионально-педагогической деятельности включают умения профилактики персональных и коллективных аппаратных и программных средств на предмет защиты, умения выявления и обезвреживания компьютерных вирусов.

Самое главное, на преподавателе среднего профессионального образования лежит ответственность за «обучение и воспитание обучающихся актуальным общим требованиям информационной безопасности с учетом будущей как профессионализации, так и информационной безопасности личности в условиях информационной экономики и информационного общества» [8].

И не менее важно, «сформировать и наполнить подготовку в области информационной безопасности личности, прежде всего, социальным содержанием, поскольку именно социальные её аспекты носят гносеологический, основополагающий характер» [3].

Что касается содержания повышения квалификации преподавателей среднего профессионального образования, то теоретические знания и практические умения в области информационной безопасности личности и защиты информации рассматриваются как «инвариантной составляющей информационной подготовки, направленной на формирование информационной культуры личности, требуется системный подход, реализующий методологические, организационные, содержательные, дидактические и технологические аспекты» [11].

Под информационной культурой личности понимается уровень развития человека и общества, характеризуемый значимостью задачи обеспечения информационной безопасности в системе личных и социальных ценностей, распространенностью стереотипов безопасного поведения в сети.

Как справедливо утверждают О.А. Козлов и В.П. Поляков, формирование и развитие информационной культуры, как основы информационной безопасности личности, является прямой обязанностью системы образования [8].

Информационная культура педагога может быть представлена как «относительно целостная подсистема общей и профессиональной культуры человека, являющаяся результатом поэтапного освоения информационных и коммуникационных технологий в процессе информационной подготовки, состоящая из нескольких взаимосвязанных структурных компонентов» [15].

Таким образом, решение проблемы информационной безопасности личности видится в формировании информационной компетенции преподавателей среднего профессионального образования в системе повышения квалификации.

В тоже время, ИКТ-компетенции преподавателя являются лишь одним из условий организационно-методического обеспечения информационной безопасности личности. Решение проблемы лежит в развитии информационной культуры современного общества. 


\section{Выво $\Delta ы$}

Педагогическая компетентность преподавателя среднего профессионального образования в числе предметно-методических и психолого-педагогических компетенций, включает информационные компетенции.

Информационная компетентность рассматривается как система знаний и умений педагога в области информационных и коммуникационных технологий, а также практического опыта их применения в образовательном процессе.

Значимость и актуальность подготовки преподава- телей среднего профессионального образования в области информационной безопасности личности не подлежит сомнению.

Информационную безопасность в образовании рассматривают относительно безопасности информационно-образовательной системы образовательного учреждения или отдельной личности.

Одним из основных требований к информационно-образовательной среде является наличие средств и методов, обеспечивающих информационную безопасность пользователей информационными ресурсами.

\section{ЛИТЕРАТУРА}

1. Балашова М.В. Формирование умений информационной самозащиты у студентов (на материале дисциплины «Библиография»): автореф. дис. ... канд. пед. наук: 13.00.08 / Балашова Марина Викторовна. Казань, 2012. 30 с.

2. Беспалов П.В. Компьютерная компетентность в контексте личностно-ориентированного обучения / П.В. Беспалов // Педагогика, 2003. №4. С.45-50.

3. Бешенков С.А., Миндзаева Э.В. Интеграция учащихся в современный информационный социум как педагогическая проблема [Текст] // С.А. Бешенков, Э.В. Миндзаева. Электронное обучение и дистанционные образовательные технологии. Теория и практика. Научное издание. Часть 1; под науч. ред. Я.А. Ваграменко, М.П. Карпенко. М.: Изд-во СГУ, 2017. С. $43-53$.

4. Богатырева Ю.И. Информационная безопасность школьников в образовательной среде: теория и практика высшей школы [Текст] / Ю.И. Богатырева. Тула: ТулГУ, 2013. 160 с.

5. Грачев, Г.В. Личность и общество: информационно-психологическая безопасность и психологическая защита [Текст] / Г.В. Грачев. М.: ПЕРСЭ, 2003. 304 с.

6. Ионова, 0.Н. Формирование информационной компетентности взрослых в процессе дополнительного образования: дисс. ... канд. пед. наук: 13.00 .08 / Ионова Ольга Николаевна. Великий Новгород, 2007. 173 с.

7. Камашев С.В. Безопасность российского образовательного пространства: формирование современной социально-философской концепции: дис. ... док. философ. наук: 09.00.11 / Камашев Сергей Владимирович. Новосибирск, 2016. 380 c.

8. Козлов 0.А., Поляков В.П. Информационная безопасность личности: актуальные педагогические аспекты. Наука о человеке: гуманитарные исследования. 2018. № 3 (33). С. 105-112.

9. Лобанова Н.Н. Профессионально-педагогическая компетентность преподавателей системы повышения квалификации и переподготовки специалистов как условие совершенствования их образования // Профессионально-педагогическая компетентность преподавателей системы подготовки, повышения квалификации и переподготовки специалистов: Проблемы, поиски, опыт. Санкт-Петербург, 1992.

10. Ожегов С. И. Словарь русского языка / под ред. Н. Ю. Шведовой. М. : Рус. яз., 1984. 797 с.

11. Симонова И.В., Козлов 0.А., Бочаров М.И. Дидактические единицы по основам информационной безопасности в стандартах подготовки специалистов для системы образования. // Современные информационные технологии и ИТ-образование. 2012. № 8. С. 447-456.

12. Федосеев А.А. 0 моделях и методах использования информационных технологий в обучении // Системы и средства информатики. Вып. 8. М.: Наука, Физматлит, 1996. С. 54-68.

13. Тараскина С.Н. Формирование профессиональной компетенции в области информационной безопасности преподавателей среднего профессионального образования // Педагогическая информатика. 2019. №3. С. 86-92

14. O.A. Kozlov, D.G. Rodionov, L.A. Guzikova. Information security problems in educational institutions in conditions of network interaction // International Conference on Information Networking. 2018. P. 267-269.

15. Irena V. Robert, Viktor P. Polyakov, Oleg A. Kozlov. Information security of the personality of the subjects of the educational process // SHS Web of Conferences 47 , 01059 (2018) ICPSE 2018.

(c) Козлов Олег Александрович (ole-kozlov@yandex.ru), Тараскина Светлана Николаевна (zam-po-vr@mail.ru). Журнал «Современная наука: актуальные проблемы теории и практики» 